DOI: https://doi.org/10.30525/978-9934-26-108-4-7

Svitlana Piasetska-Ustych

Candidate of Economic Sciences, Associate Professor, Associate Professor of Economic Theory Department

State University «Uzhhorod National University»

\title{
SYSTEMS OF CORRUPTION IN UKRAINE: CAUSES AND CONSEQUENCES
}

\section{Summary}

The article considers theoretical and methodological basis of corruption as a systemic problem. Corruption is analyzed as a complex socio-economic phenomenon, its main types are studied, the main approaches in economic theory to the interpretation of the concept of corruption are systematized, the causes of corrupt economic relations are clarified. Specific factors that determine the development of corruption and its consequences in the socioeconomic system of society are studied.

The study analyzes causes of corruption and shadow economic relations in Ukrainian economy, it shows that the shadow activity of market participants leads to negative socio-economic consequences for the state and society: it destructs competition, distorts the market mechanism, tax and monetary system, has a negative impact on the state of public finances. Shadow processes cause significant deformations of the social sphere.

The analysis allows us to conclude that corruption-shadow relations are systemic problems of national economy development, which are not only a threat to national security, but also create a multiplicative negative impact on socio-economic system of society.

\section{Introduction}

The problems of corruption interaction in Ukrainian society today have reached the level of a global phenomenon, when corruption in the country forms a certain system of socio-economic closely intertwined relations.

Corruption increases when there is a desire to obtain economic rent through the political process that is the state regulation of various spheres of economic life. Taking this principle as a basis, representatives of bureaucracy, politics, business and all interested groups try to subordinate state authority to private interests, which leads to "privatization of the state». This turns corruption into a systemic factor that affects all spheres of society.

That is why it is necessary to develop and implement effective socioeconomic strategies to combat corruption at all levels of socio-economic organization.

The bases of the study of corruption as a systemic problem of modern society are laid in the works of D. Akemolg, T. Varier, L. Wilde, J. Jones, 
D. Kaufman, J.-J. Laffont, S. Rose-Ackerman [18], J. Hellman, H. de Soto [2], W. Tanzi, L. Wilde, M. Philp, S. Huntington and others.

The works of A. Alatas [1], R. Vishny, R. Klitgaard [8; 9], F. Mendes, P. Haywood, E. Feig [8], F. Schneider [22] are devoted to the formation of an expanded interpretation of the concept «corruption», measurement and typology of corrupt economic activity.

Considerable attention to the study of the shadow economy and corruption is paid in the works by S.Yu. Barsukova, A.S. Vahrushev, S.M. Gurieva, V.O. Ispravnikov [6], T.I. Koriagina, S.P. Yuhachov, S.M. Echmakov [3], V.M. Polterovich [14] and others.

The development of problems related to corruption and shadow economy and the need for their significant restriction are in the interests of domestic specialists, such as: A. Bazyliuk, Z. Varnaliy [24], A. Voloshenko [25], V. Goncharova, I. Dlugopolsky, I. Mazur [10], V. Predborsky [15], R. Pustoviyt [16], T. Tyshchuk, Yu. Kharazishvili, M. Fomina [5], A. Skrypnyk [21], Yu. Samaeva [19] and others.

Analysis of corruption in Ukraine as a complex socio-economic phenomenon is possible only with a clear differentiation of the features of corruption in domestic economy, clarifying its essence, mechanisms, forms of manifestation and consequences for the development of society.

The purpose of the article is a systematic analysis of corruption processes in Ukraine, the study of the causes, nature and content of corruption models; elucidation of the peculiarities of their manifestation in modern Ukrainian economy. The importance of this problem is determined by the presence of deep systemic economic and social conflicts in the development of Ukrainian society nowadays.

\section{Part 1. The peculiarities of corruption processes in modern Ukrainian economy}

Corruption and the shadow economy accompany the development of any state, regardless of its socio-economic, political, social structure. For example, the first mention of the struggle against corruption dates back to the second half of the 24th century B.C. (Sumerian city-state Lagash).

Corruption came with the emergence of the state. Bribery as a crime involving severe punishment is mentioned in the Code of Hammurabi (2200 BC). Despite the fact that in the early stages of its development, human society considered corruption a social evil, in some countries the attitude to it was relatively loyal, and in some countries corruption was even legalized.

According to chroniclers, bribes appeared in ancient Russia, and immediately evoked a decisive counteraction. By the 18th century officials in Russia lived on so-called «feeding» or «offerings». In Soviet times, corruption manifested itself in the form of status rent, which could be used primarily by the party nomenclature. 
At the current stage of development of the Ukrainian state, corruption has become a systemic socio-economic phenomenon.

However, traditionally corruption was seen primarily as moral, then as legal, and only in the 1970s corruption began to be studied as an economic category within the theory of rent [18]. Corrupt economic relations develop when the economic interests of an entity that has the potential to obtain a status rent cannot be satisfied within the current rules and restrictions.

In the modern economic literature, the most common approaches are those in which corruption is seen as:

- a form of economic behavior chosen from an existing (available) set of alternatives;

- any actions of an individual, government agency, private company that violate the law or undermine trust in it for profit or other gain;

- use of official position and public funds to improve the personal wellbeing and well-being of the family and close relatives.

A significant amount of economic research on the phenomenon of corruption emphasizes the existence of close relationship between high levels of corruption in society and disproportionately high incomes of a small group of people and growing poverty of the majority of population [20].

We share the view of $\mathrm{R}$. Klitgaard, who for decades studied the phenomenon of corruption [8; 9] and describes the propensity to corruption as a formula that includes low risk, moderate punishment and high profits:

Corruption $=$ Monopoly + Freedom of action - Accountability .

From a functional point of view, corruption can be described as:

1) the use of state power in personal interests;

2) general concept that reflects a significant number of different types of behavior, including outright theft (when public funds or public property are used by officials for their enrichment) and personal interest (when a corrupt official receives personal financial gain as a result of the decisions he makes, within the performance of official duties).

Researchers determine that today corruption exists in various sectors of the economy of many countries and is one of the main factors hindering their development [2]. Thus, the corruption component of economic activity is a dangerous problem and requires a detailed assessment of a number of interactions (especially in the public sector) from the standpoint of the existing corruption component.

The following main signs of corruption can be identified:

- mutual agreement of the participants in the action;

- existence of mutual obligations;

- obtaining certain benefits for both parties;

- making a decision that violates the law or contradicts moral standards;

- conscious subordination of public interests to personal gain;

- both sides try to hide their actions. 
Types of corruption

\begin{tabular}{|l|l|}
\hline \multicolumn{1}{|c|}{ Criteria } & \multicolumn{1}{|c|}{ Types of corruption } \\
\hline Who is abusing official position & - Household \\
& - Political \\
& - Business \\
\hline $\begin{array}{l}\text { Who is the initiator of corrupt } \\
\text { relations }\end{array}$ & $\begin{array}{l}\text { - Extortion of bribes by a manager } \\
\text { - Bribery at the initiative of the petitioner }\end{array}$ \\
\hline Who gives a bribe & $\begin{array}{l}\text { - Individual bribe } \\
\text { - Entrepreneurial bribe } \\
\text { - Criminal bribery }\end{array}$ \\
\hline $\begin{array}{l}\text { Form of the benefit of the } \\
\text { person who received the bribe }\end{array}$ & - Cash bribe \\
\hline $\begin{array}{l}\text { Objectives of corrupt relations } \\
\text { from the point of view of the } \\
\text { bribe-giver }\end{array}$ & $\begin{array}{l}\text { - Accelerating bribe } \\
\text { - Brake bribe }\end{array}$ \\
\hline $\begin{array}{l}\text { The degree of centralization of } \\
\text { corrupt relations }\end{array}$ & $\begin{array}{l}\text { - Bribe for «good relations» } \\
\text { - Centralized bottom-up corruption } \\
\text { - Centralized top-down corruption }\end{array}$ \\
\hline $\begin{array}{l}\text { The prevalence of corruption } \\
\text { relations }\end{array}$ & $\begin{array}{l}\text { - Top corruption } \\
\text { - Grassroots corruption } \\
\text { - International corruption }\end{array}$ \\
\hline $\begin{array}{l}\text { The degree of regularity of } \\
\text { corrupt relations }\end{array}$ & $\begin{array}{l}\text { - Episodic corruption } \\
\text { - Systematic (institutional) corruption } \\
\text { - Kleptocracy (corruption as an integral component of } \\
\text { power relations) }\end{array}$ \\
\hline
\end{tabular}

Corruption as a choice of rational agents is analyzed within the framework of neoclassical theory, which considers corruption as a kind of shadow tax on the private sector, and this tax is obtained by politicians and officials due to the monopoly on making important business decisions. At the same time, corruption (like any other type of crime) is a very risky activity because someone who pays bribes or takes bribes risks being caught and convicted.

Researchers analyze models based on a comparison of the expected benefits and possible losses from corrupt practices. If the expected benefit is greater than zero, it becomes an incentive for corruption and vice versa [9].

Representatives of the neoclassicism offer a variety of sanctions (fines, confiscation of property) as the main ways to reduce corruption, seeing these sanctions as a real loss from corruption.

What effect do governmental measures against corruption have? The high probability of being caught reduces the volume of corrupt services, but increases the amount of bribes. On the contrary, the dependence of punishment on the amount of bribe reduces the size of the latter, but increases the quantity of bribes.

Neoclassical models do not take into account the «inclusion» of an individual into social environment and do not pay attention to the factors that 
affect potential participants in corrupt transactions, such as morality and public condemnation of criminal behavior.

In contrast to the neoclassicism, within the institutional approach, corruption is studied as the interaction of people in social environment, in connection with which the main factors holding back corruption are:

- ideology;

- professional ethics;

- corporate culture;

- family tradition;

- religion;

- social norms.

Considering above mentioned, the greatest importance is attached to social norms, according to which corrupt behavior can be justified or rejected. At the same time, social norms are extremely inert, and changing them is a long-term process. In our opinion, it is the lack of public condemnation, the mass spread of «grassroots», "domestic» corruption, that has led to the flourishing of systemic corruption in Ukraine [12].

Table 2

Main approaches to the interpretation of corruption as a concept

\begin{tabular}{|c|l|}
\hline Concept & \multicolumn{1}{c|}{ Summary } \\
\hline $\begin{array}{c}\text { Rationalist approach } \\
\text { (crime economics) }\end{array}$ & $\begin{array}{l}\text { The individual weighs all the costs and benefits of the } \\
\text { criminal actions and rationally decides to commit a } \\
\text { crime if the expected usefulness of such actions is } \\
\text { higher than if it remained law-abiding and spent } \\
\text { personal time and resources in another way. }\end{array}$ \\
\hline $\begin{array}{c}\text { Theory of rent-oriented } \\
\text { behavior }\end{array}$ & $\begin{array}{l}\text { Economic rent - payment for resources above the } \\
\text { maximum value of opportunity costs in the non- } \\
\text { monopoly use of these resources. Rent-oriented } \\
\text { behavior - efforts aimed at government intervention in } \\
\text { the market allocation of resources in order to } \\
\text { appropriate the artificially created income in the form } \\
\text { of rent. Corruption is understood as a form of illegal } \\
\text { rent-oriented behavior. }\end{array}$ \\
\hline $\begin{array}{c}\text { Institutional approach } \\
\text { Model }\end{array}$ & $\begin{array}{l}\text { Corruption is a contractual interaction between } \\
\text { economic agents in order to abuse a position for } \\
\text { private gain. }\end{array}$ \\
\hline «Principal - agent» & $\begin{array}{l}\text { Corruption exists due to the asymmetry of information } \\
\text { and the high cost of monitoring the activities of an } \\
\text { agent-official. }\end{array}$ \\
\hline Theory of opportunistic \\
behavior
\end{tabular}$\quad$\begin{tabular}{l} 
Corruption is a special case of opportunistic behavior \\
\hline $\begin{array}{c}\text { Classical liberalism } \\
\text { Corruption as a «failure of the state» and as a «failure } \\
\text { of the market», as a «public anti-good» that harms all } \\
\text { members of society (negative externalities) }\end{array}$ \\
\hline
\end{tabular}


One of the main manifestations of corruption is the formation of corrupt rents. The term «rent» is widely used in economic theory and is applied to factors of production - labor, land, capital. Formation of rent is associated with owning a scarce resource and having a limited supply. Such a resource for corrupt officials at various levels of government is access to public resources (including investment and financial resources) [20]. Systemic corruption has the ability to guarantee businesses receiving governmental or municipal orders, thus providing a stable source of funding for its business activities (through a successful tender, participation in a program or a specific investment project). Corruption often deliberately creates barriers to business, artificially limiting its supply and depriving it of significant benefits. These circumstances can be compared with the situation, which in economic theory is defined as the formation of monopoly profits or monopoly rents.

The existence of systemic corruption can be compared to the conditions of a closed monopoly, barriers, regulations, political lobbies. A closed monopoly guarantees a net economic profit, which in this case turns into a corrupt rent. The amount of corrupt rents depends, on the one hand, on the «market price» of contracts awarded to businesses by the authorities, on the other hand, they are affected by the amount of costs associated with finding corrupt rents. In this case, the costs of a closed monopoly include court fees, which arise due to a number of circumstances caused by the «dissatisfaction» of private business, maintenance of lobbyists of various branches of government.

In the environment of monopolistic behavior of the state authority representatives, absence of resources - substitutes is natural; inefficient allocation of existent natural resources available under a closed monopoly only to a limited extent (with constant elasticity of demand for them).

The source of monopoly power of systemic corruption should be considered a high concentration of corrupt officials at various levels of government, as well as their seizure and control over the distribution of a significant part of state resources. From the course of political economy, it is known that closed monopolies are the most serious threat to the market, their operation causes the formation of net gross product costs (domestic and regional).

According to many scholars, corruption was the cause and consequence of the functioning of the shadow economy, which led to significant property differentiation of society, declining morality and degradation of sociopolitical life [3; 5].

\section{Part 2. Consequences of systemic corruption in Ukraine}

The corruption component is present today in both the corporate and private sectors of the economy. Corruptors do not obey the regulatory rules that are set for market participants (or successfully manipulate them). They take certain risks, abusing their position, knowing that the negative 
consequences of their decisions will be paid for by taxpayers. The status granted to a corrupt official provides him with economic immunity in society.

It is possible to identify the main factors that contribute to the development of corruption and shadow relations in modern Ukraine [11]:

1. Financial and economic:

- unfair initial distribution of capital - the shadow sector provides a redistribution of GDP (sooner or later, but Ukraine will have to solve the problem of predatory privatization and oligarchic capital - it is not about «dekulakization of the oligarchs» but about restoring justice in the distribution of national wealth and personal and public property lost by citizens);

- imperfection of the tax system - so far in Ukraine a significant part of GDP is collected in the budget and state funds, which is then stolen;

- large-scale embezzlement of budget funds that has been going on for many years (according to expert estimates, from 10 to 20\% of all financial resources allocated for the implementation of state programs and projects, as well as profits of state enterprises are stolen and laundered through the shadow economy);

- the lack of a state systemic policy of economic and social incentives for enterprises to come out of the shadows (replacing such a policy with highprofile campaigns only leads to an increase in corruption);

- archaic structure of finance (today the money in circulation in the shadow economy outside the Ukrainian banks (cash in hryvnia and foreign currency and non-cash abroad) constitutes, according to expert estimates, an astronomical amount approximately equal to the total money supply M2).

2. Legal:

- significant inconsistencies and gaps in the legislation that contribute to irresponsibility in illegal activities, with excessive regulation of open business activity;

- a largely corrupt system of law enforcement and the judiciary (the shadow economy breeds corruption, and corruption, in turn, creates a basis for the development of the shadow economy);

- vulnerability of open effective private business from arbitrariness of officials, «law enforcement terror», encroachments of crime and corporate raiding of «oligarchs».

3. Administrative:

- the lack of an effective state management vertical, which would cover all areas of the economy throughout Ukraine and aimed not at «appropriation» of the budget and not at direct intervention in the economy but at effective business development;

- prohibitory, punitive administration - excessive formal administrative barriers that hinder the development of legal business, the bureaucracy's focus on the negative rather than the positive; 
- irresponsibility and incompetence of the state administrative apparatus, the lack of dependence of the official's salary on the specific results of their work for the development of open market relations in the economy.

4. Social and political:

- the uncertainty of most entrepreneurs in the stability of market economic course of the state due to the lack of a clear development strategy and strengthening the direct participation of the state in the economy;

- social and political insecurity of the majority of the population - the state has separated itself by irresponsibility from citizens, and citizens in return do not consider themselves obliged to such a state;

- degradation of culture, morality, propaganda of the cult of crime and permissiveness, lack of education system of younger generation.

Analyzing the negative impact of corruption on economic growth, it should first be noted that this applies to medium and large businesses, as well as public investment, when there is a serious excess of project value due to the fact that participants in corrupt relations receive as income a portion of budget funds. This is a negative factor even when the program is successfully implemented, because in this case the income of corrupt officials is provided by honest taxpayers, which is the main and dangerous side effect of corruption [3; 18].

A number of experts note the following negative consequences of corruption:

- weakening the role of the law;

- reducing the confidence of economic agents in the state;

- slowdown in economic growth;

- increasing social inequality;

- decrease in business activity;

- deterioration of the investment climate $[8 ; 14 ; 20]$.

Thus, it can be argued that the consequence of corruption is formation of unproductive patterns of behavior of both public sector and business structures, as corruption causes restrictions on competition, slowing down the pace and quality of economic growth.

At the same time, there is an increase in demand for corrupt services, which indicates that such patterns of behavior are becoming more common among economic agents, especially in countries with undeveloped markets. The main reason is that corruption allows for higher incomes compared to legal forms of doing business. All this weakens the incentives to invest in the real sector of the economy. This is extremely important for the Ukrainian economy in terms of unstable macroeconomic forecast, when the number of budget problems is steadily growing [13].

According to the IMF, the annual amount of bribes in the world is 2 trillion USD. In 2013, the European Commission estimated the annual losses of the economy from corruption in the EU member states at about 120 billion EUR [23]. 
The phenomenon of corruption in Ukraine reflects the internal contradictions of the socio-economic system of the country. Moreover, it should be noted that corruption in Ukraine arises and reproduces in specific conditions. At the same time, the close link between corruption and the shadow economy is quite obvious: without illegal transactions and tax evasion, a large part of the business (especially small ones) would not be able to pay bribes and «rewards».

Corruption manifestations, according to the current legislation, include:

- abuse of power and official position;

- receiving a bribe;

- commercial bribery;

- other illegal use by a person of his official position contrary to the legitimate interests of society and the state for profit in the form of money, valuables, other property.

The basic principle of corrupt relations is that the acts of corruption are beneficial to both parties.

Table 3

\section{Determinants of corruption}

\begin{tabular}{|l|l|}
\hline Types of factors & Factors \\
\hline Fundamental & $\begin{array}{l}\text { Imperfection of economic institutions and economic policy; } \\
\text { inadequacy of political decision-making, underdevelopment of } \\
\text { competition, excessive government intervention in the economy, } \\
\text { monopolizing of particular sections of the economy, low level of } \\
\text { civil society development, ineffectiveness of the legal system. }\end{array}$ \\
\hline Legal & $\begin{array}{l}\text { Weakness of the law, absence of a clear legislative base and overly } \\
\text { frequent changes to economic legislation, breaches of international } \\
\text { law norms, insufficient enforcement of anti-corruption agreements, } \\
\text { the ability to illicitly influence judicial processes, the existence of } \\
\text { norms allowing for subjective interpretation of objective actions. }\end{array}$ \\
\hline Organizational/ \\
economic & $\begin{array}{l}\text { Weakness of the control system over distribution of public resources } \\
\text { (particularly natural resources), cumbersome and ineffective } \\
\text { bureaucratic apparatus, relatively low salaries of public officials, } \\
\text { discrimination in access to infrastructure networks, significant trade } \\
\text { protectionism (tariff and non-tariff barriers), other forms of } \\
\text { discriminations. }\end{array}$ \\
\hline Informational & $\begin{array}{l}\text { Lack of transparency in government mechanisms, informational } \\
\text { asymmetry, the absence of real freedom of expression and press, the } \\
\text { existence of offshore zones, absence of research into corruption. }\end{array}$ \\
\hline Social & $\begin{array}{l}\text { Clan-based structures, nepotism as a tradition, exploitation of } \\
\text { connections, blat (system of informal connections/agreements as a } \\
\text { form of corruption), tradition of gifts and bribes, low level of } \\
\text { education and literacy. }\end{array}$ \\
\hline Cultural-historical & $\begin{array}{l}\text { Formation of a system of bureaucratic behavioral norms, mass } \\
\text { culture which excuses corruption, specifics of historic development, } \\
\text { limited importance being placed on honor and honesty. }\end{array}$ \\
\hline
\end{tabular}


In Ukraine, corruption, according to research, has become systemic and has become an independent political force. It is now characterized by the following features:

a) public policy is directly dictated by the private interests of persons in power, close to power, or able to influence power;

b) additional and shadow incomes form the basis and necessary part of the income of officials;

c) corrupt behavior has become the norm of economic and legal culture;

d) the executive power actively uses «shadow» forms of income mobilization and stimulation [3].

Significant growth in the shadow economy began in 2013, with a further increase in the shadow sector due to price and devaluation shocks, escalation of the military conflict and COVID-19.

Table 4

\section{Consequences of systemic corruption}

\begin{tabular}{|c|c|c|}
\hline Political sphere & Economic sphere & Social sphere \\
\hline $\begin{array}{l}\text { Impossibility of } \\
\text { implementing democratic } \\
\text { principles }\end{array}$ & $\begin{array}{l}\text { Inefficient allocation and } \\
\text { use of public funds and } \\
\text { resources }\end{array}$ & $\begin{array}{l}\text { Rising social inequality, } \\
\text { poverty }\end{array}$ \\
\hline $\begin{array}{l}\text { Shifting policy goals from } \\
\text { national development to } \\
\text { ensuring the dominance of } \\
\text { oligarchic groups }\end{array}$ & $\begin{array}{l}\text { High time and material costs } \\
\text { for doing business; growth } \\
\text { of financial and commercial } \\
\text { risks }\end{array}$ & $\begin{array}{l}\text { The inability of the } \\
\text { authorities to solve social } \\
\text { problems through } \\
\text { «kickbacks» to the detriment } \\
\text { of the budget sphere }\end{array}$ \\
\hline Violation of the rule of law & $\begin{array}{l}\text { Search for rent due to losses } \\
\text { in material production }\end{array}$ & Increasing organized crime \\
\hline $\begin{array}{l}\text { Inefficiency of political and } \\
\text { judicial institutions }\end{array}$ & $\begin{array}{l}\text { Distortion (increase) of } \\
\text { prices }\end{array}$ & Impunity for crimes \\
\hline $\begin{array}{l}\text { Decreased trust in the } \\
\text { government, its alienation } \\
\text { from society }\end{array}$ & $\begin{array}{l}\text { Decreased competition and } \\
\text { loss of economic development }\end{array}$ & Formation of mafia groups \\
\hline $\begin{array}{l}\text { Falling prestige of the } \\
\text { country }\end{array}$ & $\begin{array}{l}\text { Growth of the shadow } \\
\text { economy, losses of tax }\end{array}$ & $\begin{array}{l}\text { Discrediting the law in the } \\
\text { eyes of society }\end{array}$ \\
\hline $\begin{array}{l}\text { Disappearance of real } \\
\text { political competition }\end{array}$ & $\begin{array}{l}\text { Deterioration of the investment } \\
\text { climate, reduced investment }\end{array}$ & $\begin{array}{l}\text { Moral and ethical norms } \\
\text { lose their meaning }\end{array}$ \\
\hline State fiasco & $\begin{array}{l}\text { Decreased efficiency of the } \\
\text { country's economy as a } \\
\text { whole }\end{array}$ & $\begin{array}{l}\text { Increasing income } \\
\text { differentiation, social } \\
\text { tension }\end{array}$ \\
\hline
\end{tabular}


Corruption has become a system-forming factor in the process of merging the functions of private business and public administration. The fact that both government and business are involved in corruption makes the struggle against corruption an extremely difficult area of public policy.

Specific factors that determine the nature of the development of corrupt economic relations in modern Ukraine, on the one hand, are conditioned by historical heritage (tolerant attitude in society to corruption combined with low legal literacy; the existence in Ukraine of informal «spontaneous» civil society, which has more significant influence than the Western models of civic institutions introduced into Ukrainian practice; a wide range of discretionary powers of officials), and on the other hand, are due to socioeconomic realities of Ukrainian society (scale of shadow economy; inefficiency of formal institutions; high level of social inequality; low level of non-cash payment prevalence, unsatisfactory conditions for the realization of economic interests of civil servants of different levels).

The negative economic consequences of corruption in the modern economic literature include the following:

- growth of the shadow economy in terms of reducing tax revenues of budgets of all levels;

- loss of confidence of economic entities in the ability of the government to determine and ensure the rules of the market;

- reducing the effectiveness of competitive market mechanisms and discrediting market competition;

- price increase through corruption overheads which are transferred to buyers;

- irrational use of budget funds in the distribution of state and municipal orders, benefits, guarantees, subsidies.

Reproduction of corruption causes the following social consequences: discrediting the legal regulator of interaction between the state and society; diversion of significant resources from the state budget to social development; growing social instability in society; increasing economic and political risks of business organization, which worsen Ukraine's investment rating in the world.

Algorithm for successful counteraction by the state and society to corruption and shadow economic relations include [12]:

1) legitimate elite of society and the state;

2) ideals and moral attitudes, adequate to society and its progressive development, must be implanted in the public consciousness;

3) improvement of transparent relations of society, including in the field of economy, giving them a powerful impetus to sustainable progressive development;

4) reforming the regulatory framework of the state for bringing it in line with ideals and moral attitudes, on the one hand, and real life, including economic, on the other; 
5) weakening of the shadow sphere of society and economy;

6) weakening of shadow elites and shadow centers of power;

7) elimination of the roots of the shadow and criminal spheres of society, including economic.

Currently, Ukraine's Corruption Perceptions Index (CPI) has deteriorated and is 33 points out of 100 , which is 3 points more than last year. According to Transparency International, in The Global Corruption Barometer 2020, Ukraine ranks 117th out of 180 positions. Last year, the country was ranked 126th out of 180 [23].

Procrastination with the real punishment of bribe-takers, as well as the increase in corruption component in relations between business and government do not allow Ukraine to take a decisive step forward in terms of CPI. And seven years after the Revolution of Dignity, Ukraine remains the most corrupt country in Europe. The conditions for long-term business are difficult. The main reasons are corrupt protectionism and merging of political and business interests.

Ukraine has not overcome the limit of «corruption shame», remaining in the club of totally corrupt states.

\section{Conclusions}

Corruption as an economic phenomenon is latent, illegal, which is realized through rent-oriented behavior of officials, a form of socially unauthorized relations of exchange, distribution and appropriation of economic goods, money, securities and assets that restrict economic freedom, competition and access to national and business resources. Under these conditions, corrupt officials, who are endowed with power functions in the system of public administration, illegally commercialize their activities, convert power into property and capital, and provide non-economic advantages in competition (primarily in resource markets) to business representatives who pay corrupt rents.

The existence of a close corruption link between government and business in Ukraine (as opposed to other countries where it is less visible or incidental) makes corruption an institutional phenomenon. The persistence of corrupt ties is a determining factor in the characterization of Ukrainian reality and poses a serious public danger, as it creates significant corruption webs that not only make a profit from their illegal activities, but also invest them in the development of corruption itself. This turns corruption into a systemic factor of the Ukrainian socio-economic model of society.

Lack of political will is largely a consequence of the involvement of senior government officials in political and corrupt actions, their interest in certain corruption schemes.

Therefore, real anti-corruption policy should take into account the following factors: 
- state authorities are corrupt and therefore not interested in the real combat against corruption;

- in Ukraine, unfortunately, there are no influential politicians, real «moral leaders» who are ready to be a «moral example» and lead the fight against corruption;

- society shows mostly «silent indignation» at the manifestations of political and economic corruption and does not actively oppose it;

- a significant part of society has adopted corrupt «rules of the game» and acts in accordance with them;

- political and economic corruption has a solid basis - the oligarchic-clan economy, which is not interested in introducing transparent rules of business activities and bringing them closer to European standards;

- Ukraine, as a member of international organizations, has undertaken certain commitments to combat corruption, some of these commitments are being fulfilled (for example, e-declaration of income of high-ranking officials);

- there is a high level of public dissatisfaction with the corruption of government and political forces and a critically low level of public confidence in them;

- currently, a significant number of state structures have been formed and operate in Ukraine to prevent and combat corruption, but so far their effectiveness is almost zero.

\section{References:}

1. Alatas S.H. (1990) Corruption: its Nature, Causes and Concequences. Aldcrshot: Avebury, ch.1.

2. Ernando de Soto (1995) Nevidimaya revoliutsiya v tretiem mire [Another way. Invisible revolution in the third world]. Moscow: Catallaxy. (in Russian)

3. Echmakov S.M. (2004) Tenevaya ekonomika: analiz i modelirovanie [Shadow Economy: Analysis and Modeling]. Moscow: Finance and statistics. (in Russian)

4. Feige E.L. (1997) Undegraund Activity and Institutional Change: Productive, Protective, and Predatory Behavior in Trasition Economies. In Nelson, Tilley, Walker (ads) Transforming Post-Communist Political Economies. National Academe Press, Washington D.C., pp. 19-34.

5. Fomina M.V., Pryhodko V.V., Kapturenko M.G. et al. (Eds) (2012) Koruptsiia i tinova ekonomika: politekonomichnyi aspekt [Corruption and shadow economy: political and economic aspect]. Donetsk: DonNUENT. (in Ukrainian)

6. Ispravnikov V.O. (2007) Tenevaya ekonomika [Shadow economy (scientific and methodological manual for students of economic faculties)]. Moscow: Infra. (in Russian)

7. Ivanov Yu.B. (2010) Tinova ekonomika v konteksti kryzy derzhavnoho upravlinnia [Shadow economy in the context of the crisis of public administration]. Problems of economics, no. 4, pp. 21-24.

8. Klitgaard R. (1998) Controlling Corruption: a study of corruption and how to reduce it in developing countries. University of California Press.

9. Klitgaard R., Maclean-Abaroa R., Lindsey Parris H. (2000) Corrupt Cities: A Practical Guide to Cure and Prevention. ICS Press and World Bank Institute. 
10. Mazur I.I. (2008) Detinizatsiia ekonomiky Ukrainy: teoriia ta praktyka [De-shadowing of Ukraine's economy: theory and practice]. Kyiv: Publishing and Printing Centre «Kyiv University». (in Ukrainian)

11. Piasetska-Ustych S.V. (2016) Koruptsiia yak systemne yavyshche v ekonomitsi Ukrainy [Corruption as a systemic phenomenon in Ukrainian economics]. Prychornomorski ekonomichni studii, no. 6, pp. 5-10.

12. Piasetska-Ustych S.V. (2018) Teoretychni aspety analizu koruptsii yak systemnoho yavyshcha $\mathrm{v}$ suchasnii ukrainskii ekonomitsi [Theoretical aspects of analysing corruption as a systemic phenomenon within the modern Ukrainian economy]. Prychornomorski ekonomichni studii, no. 28, part 1, pp. 19-26.

13. Piasetska-Ustych S.V. (2020) Corrupt relations in modern society: causes and socioeconomic consequences. Prychornomorski ekonomichni studii, no. 59, part 1, pp. 17-23.

14. Polterovich V.M. (1999) Institutsionalnye lovushky s ekonomicheskie reformy [Institutional traps and economic reforms]. Moscow. (in Russian)

15. Predborskyi V.A. (2005) Detinizatsiia ekonomiky u konteksti transformatsiinykh protsesiv [De-shadowing of the economy in the context of transformation processes]. Kyiv: Condor. (in Ukrainian)

16. Pustoviyt R.F. (2015) Instytutsionalni faktory kleptokratychnoi ekonomiky [Institutional factors of kleptocratic economy]. Ekonomika Ukrainy, no. 12, pp. 26-38.

17. Revak O.I. (Ed) (2011) Koruptsiia: teoretyko-metodolohichni zasady doslidzhennia [Corruption: theoretical and methodological principles of research]. Lviv: Lviv DUVS, 220 p. (in Ukrainian)

18. Rose-Ackerman S. (2003) Korruptsiya i gosudarstvo: Prichiny, sledstviya, reformy [Corruption and State: Causes, Effects, Reforms], Logos, 356 p. (in Russian)

19. Samaeva Yu. (2016, no. 41) Shou koruptsiinoho absurdu [The Show of Corruption Absurdity]. Dzerkalo Tyzhnia. (in Ukrainian)

20. Sanjeev C., Davoodi H., Alonso-Terme R. (1998) Does Corruption Affect Income Inequality and Poverty? IMF Working Paper 76.

21. Skrypnyk A. (2009) Determinanty koruptsii v Ukraini [Determinants of corruption in Ukraine]. Ukraine economy, no. 4, pp. 29-43. (in Ukrainian)

22. The Shadow Economy in Europe. (2013) / K. Scheider, Ph.D. // ATKearney. Johmannes Kepler / Universitat Linc. JKU.

23. Transparency International 2020: Report. Corruption Perceptions Index 2020. URL: https://ti-ukraine.org/research/indeks-spryjnyattya-koruptsiyi-2020/ (accessed 19 June 2021).

24. Varnaliy Z.S. (2014) Teoretychni zasady detinizaciyi ekonomiky Ukrayiny [Theoretical principles of de-shadowing of Ukraine's economy]. Herald of Vinnytsia Polytechnic Institute, no. 1, pp. 46-51.

25. Voloshenko A.V. (2017) Ekonomichna koruptsiia yak instytutsiia systemnoruinivnoho kharakteru [Economic corruption as an institution of systemically destructive nature]. Current economic problems, no. 5. pp. 78-88. 